University of Wollongong

Research Online

Faculty of Business - Economics Working

Papers

Faculty of Business and Law

1992

\title{
An integrative analysis of external debt, capital accumulation and production in Latin America, Asia-pacific and sub-Saharan Africa
}

Amnon Levy

University of Wollongong, levy@uow.edu.au

Khorshed Chowdhury

University of Wollongong, khorshed@uow.edu.au

Follow this and additional works at: https://ro.uow.edu.au/commwkpapers

\section{Recommended Citation}

Levy, Amnon and Chowdhury, Khorshed, An integrative analysis of external debt, capital accumulation and production in Latin America, Asia-pacific and sub-Saharan Africa, Department of Economics, University of Wollongong, Working Paper 92-3, 1992, 20.

https://ro.uow.edu.au/commwkpapers/294

Research Online is the open access institutional repository for the University of Wollongong. For further information contact the UOW Library: research-pubs@uow.edu.au 


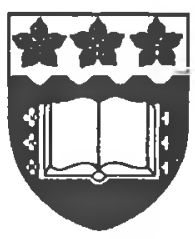

THE UNIVERSITY OF WOLLONGONG

DEPARTMENT OF ECONOMICS

AN INTEGRATIVE ANALYSIS OF EXTERNAL DEBT, CAPITAL

ACCUMULATION AND PRODUCTION IN LATIN AMERICA, ASIA-PACIFIC AND SUB-SAHARAN AFRICA

\author{
Amnon Levy \\ and \\ Khorshed Chowdhury* \\ Department of Economics \\ The University of Wollongong \\ Northfields Avenue \\ Wollongong NSW Australia
}

Working Paper 92-3 


\begin{abstract}
This paper estimates the nexus of inter-relationships between public and private external debts accumulation, capital accumulation and production within a simultaneous equation system using panel data for the period 1970-1988 from highly indebted developing countries clustered into three distinct regions: Latin-America, Asia-Pacific and Sub-Saharan Africa. The estimation results indicate that the full effects of the public and private external debts on GNP are small and of an opposite sign, whereas an increase in the GNP level raises substantially the public and private external debts. These findings support Bulow-Rogoff's proposition that the external debts of developing countries are not a primary cause of economic slowdown.
\end{abstract}

* Amnon Levy is an Associate Professor and Khorshed Chowdhury is a lecturer at the Department of Economics, University of Wollongong, New South Wales, Australia. The authors are indebted to Mei Ball for dedicated research assistance. 


\section{INTRODUCTION AND SUMMARY}

The 'Symposium on New Institutions for Developing Country Debt', which is published in the Winter 1990 issue of the Journal of Economic Perspectives, reveals a major controversy between two schools of thought about the effects of the external debt on economic growth and the role of international facilities for debt relief. The first school of thought, represented by Kenen (1990) and Sachs (1990), claims that the external debt overhang is a primary cause of economic slowdown in the highly indebted countries and hence there is an urgent need for an international debt relief facility. In contrast, the second school of thought, represented by Bulow and Rogoff (1990), claims that the external debts of developing countries are not the cause of economic slowdown, but rather a symptom of poor economic management and economic growth. This school also argues that the presence of official creditors, such as the International Monetary Fund and the World Bank, ossifies the negotiating position of the private creditors and leads to a 'free-rider' problem whereby indebted countries are likely to use the rescheduling negotiated for other indebted countries as a benchmark for obtaining better arrangements. Thus, the commercial banks are likely to take a tougher attitude toward countries which negotiate the rescheduling of their debts earlier.

In a previous study, we conducted Granger causality tests for twenty-nine highly indebted developing countries in Latin America, Asia-Pacific, Sub-Saharan Africa, Southern Europe and the Mediterranean and concluded that none of the aforementioned general propositions about the causal relationships between economic growth and external debt is valid (Levy, Chowdhury and Wilson, 1991). The Granger tests and the computations of the long-term effects of the GNP growth rate on the external debt accumulation rate indicated that Bulow-Rogoff's proposition that the level of external debt of the developing countries is just a symptom of economic slowdown is rejected for all the countries included in the study. The Kenen-Sachs' proposition that external debt leads to an economic slowdown was supported for only fifty per cent of investigated countries in Latin-America and for Sudan. Among these countries, the long-term effect of the external 
debt accumulation rate on the GNP growth rate was found to be substantially large only in the cases of Brazil, Jamaica, Venezuela and Sudan. The results for thirteen countries out of the twenty-nine indicated the existence of a feedback (bi-directional) relationship between the GNP growth rate and the external debt accumulation rate.

In order to supplement the study of the cause and effect relationships between GNP and external debt with more structural economic analysis, the present paper assesses the direct, indirect and full effects of the external debt on GNP, and vice versa, by estimating a system of simultaneous equations which displays the possible interactions between GNP, capital stock accumulation, public and publicly guaranteed external debt and private external debt accumulation. The simultaneous equation system also incorporates the effects of exogeneous and lagged-dependent variables on the aforementioned endogeneous variables. It is estimated with panel data for the period 1970-1988 on thirty-six highly indebted developing countries clustered into three distinct regions: Latin-America, Asia-Pacific and Sub-Saharan Africa.

With regard to the above-mentioned controversy, the estimates of the simultaneous equation system indicate that the full (direct and indirect) effect of GNP on public and private external debts is positive: an increase of 1 per cent in the GNP level is expected to raise the public and publicly guaranteed external debt level by $0.469,0.415$ and 1.450 per cent and the private external debt level by $0.293,0.072$ and 0.269 per cent in the cases of Latin-America, Asia-Pacific and Sub-Saharan Africa, respectively. In contrast to Kenen and Sachs' assertion, it is found that the effects of the public and private external debts on the GNP level in these regions is small: a 1 per cent rise in the public and the publicly guaranteed external debt level is likely to increase the GNP level by $0.158,0.240$ and 0.358 per cent in the cases of Latin-America, Asia-Pacific and Sub-Saharan Africa, respectively; whereas a rise of 1 per cent in the private external debt is expected to reduce the GNP level by $0.129,0.033$ and 0.016 per cent in the cases of Latin America, AsiaPacific and Sub-Saharan Africa, respectively. These magnitudes and the directions of the estimated elasticities lend support to the first half of Bulow-Rogoff's claim that the external debts of the developing countries are not a primary cause of economic slowdown. They 
indicate that an economic slowdown (that is, a decrease in the GNP level) is accompanied by lower external liabilities on behalf of the developing countries.

The other findings of the paper are as follows. The GNP has a positive direct effect on the stock of capital in Latin America, Asia-Pacific and Sub-Saharan Africa. Moreover, the effect of GNP on capital stock is indirectly amplified by the positive effect of the public external debt on capital stock in these regions; but, excluding the case of Sub-Saharan Africa, it is indirectly moderated by the negative effect of the private external debt on capital stock. In the case of Sub-Saharan Africa, the positive effect of the private external debt on capital stock reinforces the positive effect of GNP on capital accumulation. In all of the three regions, the full effect of GNP on capital accumulation is positive.

In general, Sub-Saharan African countries enjoyed better terms for repaying their public and publicly guaranteed external debt than the Asian-Pacific and Latin American countries; and the Asia-Pacific countries enjoyed better debt repayment terms than the Latin American countries. However, this order is reversed in the case of the private external debt: the toughest repayment terms have been imposed on Sub-Saharan African countries, whereas the Asia-Pacific countries enjoyed a significant degree of forgiveness and/or negative real interest rate, and the Latin American countries enjoyed the most substantial private external debt relief.

It is found that the greater the percentage of the labour force employed in agriculture, the lower the GNP level, the greater the accumulation of capital stock, the smaller the accumulation of public and publicly guaranteed external debt, and the smaller the accumulation of private external debt. In all of the three investigated regions, a negative association is found between the public and the publicly guaranteed external debt and the terms of trade. In the case of Sub-Saharan Africa, also the private external debt decreases with the terms of trade. However, the private external debt increases with the terms of trade in the case of Asia-Pacific. The ineffectiveness of the terms of trade in reducing the private external debt is also evident in the case of Latin America.

Finally, a negative, but statistically insignificant, association between the public external debt and the income share accruing to the bottom 40 per cent of the households is 
found in the case of Sub-Saharan Africa, whereas in the cases of Asia-Pacific and Latin America a positive (though insignificant in the case of Latin America) association is found. The statistically insignificant association between the public external debt and income inequality in Latin America might be explained by the severity of income inequality in this region and hence the insufficiency of small changes in income inequality levels to alter the problematic social and political situation which hampers the commitment of governments in this region to deal effectively with their external debt problem. In contrast, in the AsiaPacific region, where income is substantially more equally distributed and populist policy is less dominant, it is evident that an improvement in the public external debt problem occurs at the expense of equality in the distribution of income.

The underlying conceptual framework and estimation procedure leading to the above findings and conclusions are given in the following sections. The simultaneous equation system of GNP, capital accumulation, and public and private external debt accumulation is presented in section 2. The estimation method, data sources and estimation results are described in section 3. The estimation results are discussed and interpreted in section 4.

\section{SIMULTANEOUS EQUATION SYSTEM OF OUTPUT, CAPITAL AND EXTERNAL DEBT ACCUMULATION}

The GNP level can affect the country's level of external borrowing by increasing imports and consequently the current account deficit. Moreover, by recalling the common practice of using the external debt-GNP ratio as a measure of the external debt burden, the larger the GNP, ceteris paribus, the lower the external debt burden, and consequently, the smaller the country's financial leverage. Thus, a larger GNP can enhance the availability of external credit and at a lower cost. While the above-mentioned factors tend to increase the country's external liabilities, a larger level of GNP, ceteris paribus, can reduce a country's reliance on external sources for satisfying the domestic demand for consumer goods and financing investment in capital stock. Thus, the combined (or full) effect of GNP on the 
country's external debt can be positive, zero, or negative if the former factors overweigh, equal, or are overweighed by the latter.

In turn, one can also expect a reciprocal relationship as the country's level of indebtedness might affect the GNP level in the following ways. First, the higher the level of indebtedness, and in particular that of the business sector, ceteris paribus, the larger the country's leverage, the more limited the external sources of credit, and the greater the number of incidences of financial distress and liquidation adversely affecting the GNP level directly and indirectly through discouraging domestic investment. Second, as argued by Krugman (1989), an increase in the public and publicly guaranteed external debt might indirectly depress the level of GNP by discouraging capital formation and encouraging capital flight due to tax increase expectations. However, if a significant portion of external borrowing is directed toward financing efficient investments in productive capital, a positive correlation between the country's GNP level and its external debt can be anticipated.

These relationships are summarised in a system of simultaneous equations of aggregate production, external debt accumulation, and capital accumulation. The proposed system distinguishes between public and publicly guaranteed external debt (EDPUB) and private external debt (EDPRIV), and thus comprises four equations. The system includes state-transition variables-the lags of capital stock, public external debt and private external debts (LCAPITAL, LEDPUB and LEDPRIV)—in order to incorporate the effects of capital depreciation and debt-servicing costs on the accumulation of capital stock (CAPITAL) and the external debt, respectively.

The system also includes some socioeconomic factors, such as the total labour force participating in production (LABOR), the percentage of the country's labour force in agriculture (PLFAG), population (POP) and a measure of income inequality-the income share accruing to the bottom 40 per cent of households (INSH40). Our attempt to incorporate into the analysis additional socioeconomic factors, such as the labour-force school years completed and poverty levels, have failed due to the unavailability of data for many countries for a substantial number of years. 
The LABOR and PLFAG are introduced in the aggregate production equation. While LABOR is considered to have an effect on the GNP as a production input, the PLFAG is taken as an indicator of the level of modernisation of the production process. It is expected that the higher the percentage of the labour force in agriculture the lower the aggregate product. PLFAG is also introduced in the accumulation equations of capital and public and private external debts as an indicator of the industrial structure of the economy. Thus, PLFAG might also have an indirect effect on GNP through its effect on CAPITAL, EDPUB and EDPRIV.

The socioeconomic variables POP and INSH40 are introduced in the capital accumulation equation as indicators of the income distribution which in addition to the GNP can affect the domestic level of savings. It is hypothesised that, all other things remaining the same, the larger the population the lower the rate of savings and the smaller the capital accumulation. In contrast, the effect of INSH40 on capital accumulation is not clear, a priori. On the one hand, a higher level of income inequality (that is, smaller value of INSH40) can lead to a higher propensity to save and subsequently to a higher level of savings and investment. On the other hand, social and political dissatisfaction and unrest stemming from a substantial degree of income inequality might adversely affect domestic investment and also lead to a capital flight. Furthermore, social and political dissatisfaction and unrest reduces the government's ability and commitment to implement unpopular fiscal measures such as subsidy and wage cuts and the restrictive monetary policies necessary for alleviating the external debt problem. In view of this, INSH40 is also introduced in the public and the publicly guaranteed external debt accumulation equation.

The external debt accumulation equations also incorporate the effects of changes in the country's terms of trade (TOT). It is expected that an increase in TOT reduces the country's external liabilities. Finally, the aggregate production equation includes the squares of capital and labour (CAPITALSQ and LABORSQ, respectively) in order to assess the properties of the marginal products of these production inputs. 
The simultaneous equation system comprises the following linear equations:

The aggregate production (or GNP) function

$$
\begin{aligned}
& \text { GNP }_{i t}=a_{0}+a_{1} \text { EDPUB }_{i t}+a_{2} \text { EDPRIV }_{i t}+a_{3} \text { CAPITAL }_{i t}+a_{4} \text { CAPITALSQ }_{i t} \\
& +a_{5} \text { LABOR }_{i t}+a_{6} \text { LABORSQ }_{i t}+a_{7} \text { PLFAG }_{i t}+\varepsilon_{1 i t} .
\end{aligned}
$$

The capital accumulation equation

$$
\begin{gathered}
\text { CAPITAL }_{i t}=b_{0}+b_{1} \text { GNP }_{i t}+b_{2} \text { EDPUB }_{i t}+b_{3} \text { EDPRIV }_{\text {it }}+b_{4} \text { LCAPITAL }_{i t} \\
+b_{5} \text { PLFAG }_{i t}+b_{6} \text { POP }_{i t}+b_{7} \text { INSH } 40_{i t}+\varepsilon_{2 i t} .
\end{gathered}
$$

The public and publicly guaranteed external debt accumulation equation

$$
\begin{aligned}
& \text { EDPUB }_{i t}=c_{o}+c_{1} \text { GNP }_{i t}+c_{2} \text { LEDPUB }_{i t}+c_{3} \text { PLFAG }+c_{4} \text { TOT }_{i t} \\
& +c_{5} \text { INSH } 40_{i t}+\varepsilon_{3 i t} .
\end{aligned}
$$

The private external debt accumulation equation

$$
\text { EDPRIV }_{\text {it }}=\mathrm{d}_{0}+\mathrm{d}_{1} \mathrm{GNP}_{\mathrm{it}}+\mathrm{d}_{2} \mathrm{LEDPRIV}_{\mathrm{it}}+\mathrm{d}_{3} \text { PLFAG }_{\mathrm{it}}+\mathrm{d}_{4} \mathrm{TOT}_{\mathrm{it}}+\varepsilon_{4 \mathrm{it}} .
$$

Here, $i$ and $t$ are country and year indices, respectively; and $\varepsilon_{1}, \varepsilon_{2}, \varepsilon_{3}$, and $\varepsilon_{4}$ are random disturbances having zero mean and finite variances and covariances.

\section{DATA, ESTIMATION METHOD AND ESTIMATION RESULTS}

The simultaneous equation system described above satisfied the order and the rank conditions for identification. It is estimated with annual observations for the period 19701988 on thirty-six countries clustered into three distinct regions: Latin America, AsiaPacific, and Sub-Saharan Africa. The Latin American group comprises eighteen countries: Argentina, Bolivia, Brazil, Chile, Colombia, Costa Rica, Ecuador, El Salvador, Guatemala, Guyana, Honduras, Jamaica, Mexico, Nicaragua, Panama, Paraguay, Peru, and Uruguay. The Asia-Pacific group includes ten countries: Bangladesh, Fiji, India, 
Indonesia, Malaysia, Pakistan, Philippines, South Korea, Sri Lanka, and Thailand. The Sub-Saharan African group includes eight countries: Cote D'Ivoire, Gabon, Ghana, Kenya, Nigeria, Sudan, Tanzania, and Zaire. The underlying rationale for clustering the countries into regional groups is as follows. On the one hand, the short time series does not enable a separate estimation of the simultaneous equation system for each country. On the other hand, pooling the countries might lead to meaningless estimation results as substantial structural differences among them are not captured by the included country-specific variables. Since greater geographical affinity may facilitate transfer of both positive and negative externalities between countries, clustering the countries into regional groups can be viewed as a reasonable compromise ensuring a higher likelihood that the observations considered in the econometric analysis are generated by a relatively similar process (Levy, 1992).

The simultaneous equation system is estimated by applying three-stage least squares (3SLS) estimation procedure to pooled annual observations on countries affiliated with the same geographical region. The nominal variables GNP, EDPUB and EDPRIV are extracted from the World Tables, 1989-90 Edition, and from the World Debt Tables 1990-91. They are deflated by the US GNP deflator, and expressed in millions of 1980 US dollars. Correspondingly, the terms of trade index (TOT) is taken with 1980 as the base year (that is, $1980=100$ ) and as reported in the World Tables 1989-90. The capital stock is also taken in millions of 1980 US dollars. Since this variable is not observed, it was approximated by using the gross domestic investment figures obtained from the World Tables 1989-90 and constant annual depreciation rate $(0.1)$ as explained in the Appendix. Our sensitivity analyses reveal that the estimation results do not change dramatically when the depreciation rate is allowed to vary between 0.05 and 0.20 . The population figures are also obtained from the World Tables 1989-90 and presented in millions. The rest of the variables, including LABOR, PLFAG and INSH40, are extracted from the Social Indicators of Development 1990. LABOR is taken as the product of the total labour force and the overall participation rate, and is presented in millions. PLFAG and INSH40 are presented as percentages. 
The estimation results of the simultaneous equation system are summarised by region in Tables 1, 2 and 3 for Latin America, Asia Pacific, and Sub-Saharan Africa, respectively.

Table 1: 3SLS Estimation Results for Latin-America*

\begin{tabular}{|c|c|c|c|c|}
\hline \multirow{2}{*}{$\begin{array}{l}\text { Explanatory } \\
\text { Variables }\end{array}$} & \multicolumn{4}{|c|}{ DEPENDENT VARIABLES } \\
\hline & GNP & CAPITAL & EDPUB & EDPRIV \\
\hline \multicolumn{5}{|l|}{ Endogenous } \\
\hline GNP & & $\begin{array}{r}2.0084 \\
(10.302)\end{array}$ & $\begin{array}{r}0.1214 \\
(14.824)\end{array}$ & $\begin{array}{r}0.0216 \\
(7.4589)\end{array}$ \\
\hline CAPITAL & $\begin{array}{r}0.7360 \\
(11.6950)\end{array}$ & & & \\
\hline EDPUB & $\begin{array}{r}-1.2378 \\
(6.8979)\end{array}$ & $\begin{array}{r}2.5063 \\
(12.419)\end{array}$ & & \\
\hline EDPRIV & $\begin{array}{r}1.5378 \\
(3.4459)\end{array}$ & $\begin{array}{r}-4.4637 \\
(3.8420)\end{array}$ & & \\
\hline \multicolumn{5}{|l|}{ Predetermined } \\
\hline LEDPUB & & & $\begin{array}{r}0.5539 \\
(18441)\end{array}$ & \\
\hline LEDPRIV & & & & $\begin{array}{r}0.7035 \\
(18.368)\end{array}$ \\
\hline LCAPITAL & & $\begin{array}{r}0.0167 \\
(1.1538)\end{array}$ & & \\
\hline LABOUR & $\begin{array}{r}341.86 \\
(0.2662)\end{array}$ & & & \\
\hline CAPITALSQ & $\begin{array}{l}-5.0 \mathrm{E}-07 \\
(2.5993)\end{array}$ & & & \\
\hline LABORSQ & $\begin{array}{l}141.690 \\
(2.0748)\end{array}$ & & & \\
\hline PLFAG & $\begin{array}{r}-36.733 \\
(0.6188)\end{array}$ & $\begin{array}{r}254.60 \\
(2.1152)\end{array}$ & $\begin{array}{r}-48.680 \\
(2.0577)\end{array}$ & $\begin{array}{r}-2.9730 \\
(0.5771)\end{array}$ \\
\hline TOT & & & $\begin{array}{r}-71.354 \\
(7.3833)\end{array}$ & $\begin{array}{r}0.3478 \\
(0.1689)\end{array}$ \\
\hline POP & & $\begin{array}{r}-914.67 \\
(4.1129)\end{array}$ & & \\
\hline INSH40 & & $\begin{array}{r}162.89 \\
(1.1382)\end{array}$ & $\begin{array}{r}79.930 \\
(0.8523)\end{array}$ & \\
\hline CONSTANT & $\begin{array}{r}957.90 \\
(0.3804)\end{array}$ & $\begin{array}{r}-10754.0 \\
(2.0596)\end{array}$ & $\begin{array}{r}8101.1 \\
(4.3728)\end{array}$ & $\begin{array}{r}63.044 \\
(0.2013)\end{array}$ \\
\hline
\end{tabular}

* The t-ratios are indicated in the parentheses. 
Table 2: 3SLS Estimation Results for Asia-Pacific*

\begin{tabular}{|c|c|c|c|c|}
\hline \multirow[b]{2}{*}{$\begin{array}{l}\text { Explanatory } \\
\text { Variables }\end{array}$} & \multicolumn{4}{|c|}{ DEPENDENT VARIABLES } \\
\hline & GNP & CAPITAL & EDPUB & EDPRIV \\
\hline \multicolumn{5}{|l|}{ Endogenous } \\
\hline GNP & & $\begin{array}{r}3.1169 \\
(6.2610)\end{array}$ & $\begin{array}{r}0.0934 \\
(11.337)\end{array}$ & $\begin{array}{r}0.0021 \\
(2.4975)\end{array}$ \\
\hline CAPITAL & $\begin{array}{r}0.2843 \\
(3.7229)\end{array}$ & & & \\
\hline EDPUB & $\begin{array}{r}0.5631 \\
(2.6877)\end{array}$ & $\begin{array}{r}1.7683 \\
(2.4012)\end{array}$ & & \\
\hline EDPRIV & $\begin{array}{r}3.2594 \\
(3.3068)\end{array}$ & $\begin{array}{r}-15.3880 \\
(2.3682)\end{array}$ & & \\
\hline \multicolumn{5}{|l|}{ Predetermined } \\
\hline LEDPUB & & & $\begin{array}{r}0.4868 \\
(11503)\end{array}$ & \\
\hline LE.DPRIV & & & & $\begin{array}{r}0.8509 \\
(29.858)\end{array}$ \\
\hline LCAPITAL & & $\begin{array}{r}0.0666 \\
(1.2640)\end{array}$ & & \\
\hline LABOR & $\begin{array}{r}376.99 \\
(1.0745)\end{array}$ & & & \\
\hline CAPITALSQ & $\begin{array}{l}-2.0 \mathrm{E}-07 \\
(1.1691)\end{array}$ & & & \\
\hline LABORSQ & $\begin{array}{r}3.449 \\
(1.1956)\end{array}$ & & & \\
\hline PLFAG & $\begin{array}{r}-18.593 \\
(0.1736)\end{array}$ & $\begin{array}{r}575.22 \\
(1.7242)\end{array}$ & $\begin{array}{r}-86.805 \\
(4.4611)\end{array}$ & $\begin{array}{r}-8.1243 \\
(2.6694)\end{array}$ \\
\hline TOT & & & $\begin{array}{r}-18.092 \\
(2.1666)\end{array}$ & $\begin{array}{r}2.4253 \\
(1.9263)\end{array}$ \\
\hline POP & & $\begin{array}{r}-358.61 \\
(3.1891)\end{array}$ & & \\
\hline INSH40 & & $\begin{array}{r}-1316.30 \\
(1.2954)\end{array}$ & $\begin{array}{l}318.800 \\
(4.0055)\end{array}$ & \\
\hline CONSTANT & $\begin{array}{l}2506.60 \\
(0.4026)\end{array}$ & $\begin{array}{r}-18298.0 \\
(1.2074)\end{array}$ & $\begin{array}{r}2594.9 \\
(1.8580)\end{array}$ & $\begin{array}{l}809.690 \\
(4.0133)\end{array}$ \\
\hline
\end{tabular}

* The $\mathrm{t}$-ratios are indicated in the parentheses. 
Table 3: 3SLS Estimation Results for Sub-Saharan Africa*

\begin{tabular}{|c|c|c|c|c|}
\hline \multirow{2}{*}{$\begin{array}{l}\text { Explanatory } \\
\text { Variables }\end{array}$} & \multicolumn{4}{|c|}{ DEPENDENT VARIABLES } \\
\hline & GNP & CAPITAL & EDPUB & EDPRIV \\
\hline \multicolumn{5}{|l|}{ Endogenous } \\
\hline GNP & & $\begin{array}{r}2.0988 \\
(5.5768)\end{array}$ & $\begin{array}{r}0.7081 \\
(9.1134)\end{array}$ & $\begin{array}{r}0.0152 \\
(2.0527)\end{array}$ \\
\hline CAPITAL & $\begin{array}{r}0.5367 \\
(1.1383)\end{array}$ & & & \\
\hline EDPUB & $\begin{array}{r}0.2774 \\
(1.6489)\end{array}$ & $\begin{array}{r}0.8488 \\
(1.7509)\end{array}$ & & \\
\hline EDPRIV & $\begin{array}{r}-1.1606 \\
(2.8061)\end{array}$ & $\begin{array}{r}1.6235 \\
(2.0683)\end{array}$ & & \\
\hline \multicolumn{5}{|l|}{ Predetermined } \\
\hline LEDPUB & & & $\begin{array}{r}0.1820 \\
(4.2212)\end{array}$ & \\
\hline LEDPRIV & & & & $\begin{array}{r}1.0733 \\
(42.906)\end{array}$ \\
\hline LCAPITAL & & $\begin{array}{r}0.0466 \\
(1.8074)\end{array}$ & & \\
\hline LABOR & $\begin{array}{r}1970.10 \\
(6.0952)\end{array}$ & & & \\
\hline CAPITALSQ & $\begin{array}{c}-2.0 \mathrm{E}-05 \\
(0.7865)\end{array}$ & & & \\
\hline LABORSQ & $\begin{array}{r}-220.550 \\
(4.3492)\end{array}$ & & & \\
\hline PLFAG & $\begin{array}{r}-196.940 \\
(3.8539)\end{array}$ & $\begin{array}{r}468.25 \\
(3.8132)\end{array}$ & $\begin{array}{r}-25.905 \\
(1.4070)\end{array}$ & $\begin{array}{r}-3.1608 \\
(1.7688)\end{array}$ \\
\hline TOT & & & $\begin{array}{r}-20.586 \\
(4.2421)\end{array}$ & $\begin{array}{r}-0.8684 \\
(1.8442)\end{array}$ \\
\hline POP & & $\begin{array}{r}-441.26 \\
(3.7055)\end{array}$ & & \\
\hline ISNH40 & & $\begin{array}{r}-398.57 \\
(4.0788)\end{array}$ & $\begin{array}{r}-10.850 \\
(0.3209)\end{array}$ & \\
\hline CONSTANT & $\begin{array}{r}13649.00 \\
(2.7586)\end{array}$ & $\begin{array}{r}-28881.0 \\
(2.7487)\end{array}$ & $\begin{array}{r}2611.4 \\
(1.7175)\end{array}$ & $\begin{array}{c}267.360 \\
(1.7704)\end{array}$ \\
\hline
\end{tabular}

* The t-ratios are indicated in the parentheses. 


\section{INTERPRETATION OF THE ESTIMATION RESULTS AND CONCLUSIONS}

The empirical findings indicated by Tables 1-3 are as follows.

\section{The effect of GNP on the public and private external debts}

In the cases of Latin America, Asia Pacific and Sub-Saharan Africa, the GNP raises both the public and private external debts. An increase of 1 per cent in the GNP is likely to increase the public and publicly guaranteed external debt by $0.469,0.415$ and 1.450 per cent and the private external debt by $0.293,0.072$ and 0.269 per cent in the cases of Latin America, Asia-Pacific and Sub-Saharan Africa, respectively.

\section{The effect of the public external debt on GNP}

In the case of Latin America, the direct effect of the public and publicly guaranteed external debt on GNP is negative. Note, however, that in contrast to Krugman's capital flight argument, the indirect effect of the public and publicly guaranteed external debt on GNP through increasing the capital stock is positive and larger in absolute terms than the direct effect. Thus, in the case of Latin America, the full effect of the public external debt on GNP is positive but small: an increase of 1 per cent in the public external debt is likely to increase the GNP by 0.158 percent. Note, further, that the positive estimates of the indirect effects of the public external debt on GNP obtained in the cases of Asia-Pacific and Sub-Saharan Africa also indicate that the capital flight generated by tax increase expectations is smaller than the contribution of the public external borrowing in financing investments in capital stock. Moreover, in these cases the direct effects, and hence the full effects, of the public external debt on GNP are positive and substantially larger than in the Latin American case: an increase of 1 per cent in the public external debt is likely to directly and indirectly raise the GNP level by 0.240 per cent in the case of Asia-Pacific and by 0.358 per cent in the case of Sub-Saharan Africa. 
The effect of the private external debt on the GNP

In the cases of Latin America and Asia Pacific, the direct effect of the private external debt on GNP is positive. However, in both cases the adverse indirect effects of the private external debt on GNP through lowering private investment and the overall level of capital stock are large in absolute value and substantially exceed the direct effects. Thus, the full effects of the private external debt on GNP are negative: an increase of 1 per cent in the private external debt is likely to reduce the GNP level by 0.129 per cent in the case of Latin America and by 0.033 per cent in the case of Asia Pacific. In the case of Sub-Saharan Africa, the direct effect of the private external debt on GNP is negative, whereas the indirect effect is positive. In this case, the direct effect dominates the indirect effect and hence the full effect of private external debt on GNP is also negative: an increase of 1 per cent in the private external debt is likely to reduce the GNP level by 0.016 percent.

\section{The effect of GNP and public and private external debt on capital stock}

The GNP has a positive direct effect on the stock of capital in Latin America, AsiaPacific and Sub-Saharan Africa. Moreover, in recalling the aforementioned positive effects of GNP on the public and private external debts, the effect of GNP on capital stock is indirectly amplified by the positive effect of the public external debt on capital stock in all of the three regions; but, excluding the case of Sub-Saharan Africa, it is indirectly moderated by the negative effect of the private external debt on capital stock. In the case of SubSaharan Africa, the positive effect of the private external debt on capital stock reinforces the positive effect of GNP on capital accumulation. In all of the three regions, the full effect of GNP on capital accumulation is positive and exceeds the direct effect.

\section{The effect of capital on GNP}

The marginal product of capital is significantly positive in the cases of Latin America and Asia-Pacific: an increase of 1 per cent in the capital stock is likely to raise the GNP level by 1.289 per cent in the case of Latin America and by 0.539 in the case of AsiaPacific. The estimates associated with CAPITALSQ indicate further that these marginal 
products are diminishing. In the case of Sub-Saharan Africa, the marginal product of capital is positive but statistically insignificant. Also in this case, the marginal product of capital is found to be diminishing.

\section{The effect of labour on GNP}

Only in the case of Sub-Saharan Africa was the marginal product of labour found to be significantly positive: an increase of 1 per cent in the labour force participating in production is likely to increase the GNP level by 0.941 per cent. In this case, the estimate associated with LABSQ indicates further that the marginal product of labour is diminishing. In the cases of Latin America and Asia-Pacific, the marginal product of labour is positive but statistically insignificant.

\section{The effects of the lags of the public and private external debts}

The motion equations of the public and the private external debts are expected to have positive state-transition parameters $\left(c_{2}\right.$ and $d_{2}$ ) which are equal to one plus the accumulation rate of the public or the private external debt, respectively. The accumulation rates indicate the difference between the average real interest rate actually charged and the share of the forgiven debt. The estimates of these state-transition parameters are significantly positive in all cases, but, excluding the case of the private external debt of Sub-Saharan Africa, smaller than one. Thus, they indicate that, in all of the three regions, the shares of public and private external debts forgiven exceed the real interest rates actually charged on these debts, and/or that the contracted real interest rates are negative. In the case of the public external debt, the estimated coefficients reveal that in general Sub-Saharan African countries enjoyed better debt repayment arrangements than the Asian-Pacific and Latin American countries, and that the Asia-Pacific countries enjoyed better debt repayment terms than the Latin American countries. This result might reveal the more forgiving attitude of the official creditors toward the lower income countries. It is interesting to note that in all cases the estimates of the state-transition parameters of the private external debt are substantially greater than those of the public debts and indicate, perhaps, the stricter 
repayment terms of credit extended to private firms. This finding can be explained by the following arguments:

i. the private sector is significantly more indebted to commercial banks than the public sector,

ii. unlike the private external debt, the public external debt is a sovereign debt which can be repudiated and hence the negotiating power of government is greater than that of the private debtors, and

iii. debt discounts stem in part from altruism mixed with an awareness of equity considerations, and hence it is more likely that debt discounts would be directed toward relieving the public external debt burden.

The estimation results indicate that the toughest conditions on private external debt repayments have been imposed on Sub-Saharan African countries where the average real interest rate actually charged is about 7.33 per cent per annum. The Asia-Pacific countries enjoyed a significant degree of forgiveness and/or negative real interest rate (about 0.15 per cent) and the Latin American countries enjoyed a more substantial private external debt relief (about 30 per cent).

The effect of the lag of capital stock

The state-transition parameter of the capital-stock's motion equation ( $\left.b_{4}\right)$ is inversely related to the annual depreciation rate of capital. Thus, the estimated low values of these parameters can be seen as indicators of very high rates of capital depreciation in all three regions.

The effect of the industrial structure on GNP, capital stock and public and private external debts accumulation

The fact that the directions (that is, signs) of the estimates associated with the industrial structure variable PLFAG are identical for the three investigated regions indicates the universality of the direct effects of the industrial structure on GNP, capital and public and private external debts accumulation. The estimated direct effects indicate that the greater 
the percentage of the labour force employed in agriculture: 1. the lower the GNP level (this result is statistically significant only for Sub-Saharan Africa), 2. the greater the accumulation of capital stock, 3. the smaller the accumulation of public and publicly guaranteed external debt, and 4. the smaller the accumulation of private external debt.

\section{The effect of the terms of trade}

In all of the three cases, it is found that the higher the value of the terms of trade index the lower the public and publicly guaranteed external debt. In the case of SubSaharan Africa, it was also found that the private external debt decreases with the terms of trade. However, in the case of Asia-Pacific, the private external debt increases with the terms of trade. The ineffectiveness of the increase in the terms of trade in reducing the private external debt is also evident in the case of Latin America.

The effect of population and income inequality on the accumulation of capital stock

As expected, in all the regions the accumulation of capital stock is adversely affected by the size of the population. The underlying rationale is that, ceteris paribus, the larger the population the smaller the share of income allocated to savings. The effect of income inequality on capital accumulation is statistically significant only in the case of Sub-Saharan Africa, where a larger income share accruing to the bottom 40 per cent of households is associated with a lower level of capital accumulation. This result probably illustrates the aforementioned positive relationship between income inequality and the propensity to save. A similar result is obtained in the case of Asia-Pacific, but it was not found to be statistically significant at the five per cent level. In contrast, an opposite, but statistically insignificant, result is found in the case of Latin America. In view of the very high degree of income inequality prevailing in the Latin American countries, the adverse effect of any further deterioration of income distribution on investment through an increase in social and political instability will exceed the potential increase in domestic savings. 
The effect of income inequality on the accumulation of public external debt

Income inequality might intensify feelings of relative deprivation and hence increase social and political tension (Sen, 1973; Yitzhaki, 1979). This, in turn, reduces the government's commitment and ability to implement drastic measures such as subsidy and wage cuts and the strict monetary and fiscal policy necessary for restoring efficiency in resource allocation, curbing the inflation and improving the terms of trade, and subsequently reducing the country's external debt burden. However, it is not clear, $a$ priori, whether income inequality is positively associated with public external debt. In certain cases, wage and subsidy cuts aimed at reducing the current account deficit might come at the expense of a further deterioration in the level of income inequality. The estimation results are quite diversified in this respect. In the case of Sub-Saharan Africa, a negative, but statistically insignificant, association between the public external debt and the income share accruing to the bottom 40 per cent of the households is found, whereas in the cases of Asia-Pacific and Latin America, a positive (though insignificant in the case of Latin America) association is found. The statistically insignificant association between public external debt and income inequality in Latin America can be further explained by the severity of income inequality in this region. In this case, small improvements in income distribution are insufficient to alleviate the social and political problems which hamper the commitment and ability of many of the Latin-American governments to deal with their external debt problems. In the Asia-Pacific region, where income is substantially more equally distributed and populist policy is less dominant, it is evident that an improvement in the public external debt problem occurs at the expense of equity.

The estimation results described above highlight the complexity of the interrelationships between GNP, public and publicly guaranteed external debt, private external debt and capital stock. They also indicate the important role of intervening socioeconomic factors; such as industrial structure, terms of trade, population size and income inequality; in the determination of the GNP level and the accumulation of capital and external debts. 


\section{REFERENCES}

Bulow, J. and K. Rogoff, 'Cleaning up Third World Debt Without Getting Taken to Cleaners', The Journal of Economic Perspectives, vol. 4, no.1 (Winter 1990):3142.

IBRD, World Debt Tables 1990-91, vol. 2, Washington D.C., 1990.

IBRD, World Tables, 1989-90, Washington D.C., 1990.

IBRD, Social Indicators of Development, 1990, Washington D.C., 1990.

Kenen, P.B., 'Organizing Debt Relief: The Need for a New Institution,' The Journal of Economic Perspectives, vol. 4, no.1 (Winter 1990): 7-18.

Krugman, P.R., 'Market-Based Debt-Reduction Schemes', in Frenkel, J.A., M.P. Dooley, and P. Wickham, eds., Analytical Issues in Debt, Washington D.C.: International Monetary Fund, 1989.

Levy, A., 'An Analysis of the Potential Externalities Affecting the Borrowing Behaviour of Developing Countries,' Australian Economic Papers, 1992 (in press).

Levy, A., Chowdhury, K. and Wilson, E., 'Are the External Debts of Developing Countries a Symptom or a Cause of Economic Slowdown?', The Indian Economic Journal, Conference volume (1991):57-72.

Sachs, J.D., 'A Strategy for Efficient Debt Reduction,' The Journal of Economic Perspectives, vol. 4, no.1 (Winter 1990):19-30.

Sen, A., On Economic Inequality, Oxford: Clarendon Press, 1973.

Yitzhaki, S. 'Relative Deprivation and the Gini Co-efficient', Quarterly Journal of Economics, 93 (1979): 321-324. 


\section{APPENDIX}

\section{Reproduction of the Capital Stock's Time-Series}

In order to reproduce the unobserved capital stock's time-series from the documented gross investment (I) time-series it is assumed that the motion equation of capital stock is given by

$$
\mathrm{K}_{\mathrm{t}}=\mathrm{I}_{\mathrm{t}}+(1-\delta) \mathrm{K}_{\mathrm{t}-1}
$$

where $\delta$ denotes a constant annual depreciation rate.

Of course, if the initial capital stock $\left(\mathrm{K}_{0}\right)$ were known, the time-series of capital stock could be easily computed for a predetermined value of $\delta$ by virtue of equation A.1. In the absence of such information, the following procedure was used to assess Ko. By assuming further that

$$
K_{t}=K_{o} g t
$$

and then substituting A.2 into A.1 for $K_{t}$ and $K_{t-1}$ we obtained

$$
\mathrm{K}_{\mathrm{O}}=\frac{\mathrm{I}_{\mathrm{t}}}{\mathrm{g}^{\mathrm{t}-1}[\mathrm{~g}-(1-\delta)]}
$$

where $\mathrm{g}$ is equal to 1 plus the unknown accumulation rate of capital stock. By recalling that A.3 holds for $t$ as well as for $t-1$

$$
\frac{I_{t}}{g^{t-1}}=\frac{I_{t-1}}{g^{t-2}}
$$

and hence

$$
\mathrm{g}=\frac{\mathrm{I}_{\mathrm{L}}}{\mathrm{I}_{\mathrm{t}-1}} .
$$


Since different values of $\mathrm{g}$ are likely to be obtained for any arbitrary choice of two consecutive values of I, we considered the sample average of the right-hand side of A.5, which is an unbiased estimator of $\mathrm{g}$ :

$$
g=\frac{1}{T} \sum_{t=1}^{T} \frac{I_{t}}{I_{t-1}}
$$

We substituted $\mathrm{t}=1$ into A. 3 to obtain

$$
\mathrm{K}_{\mathrm{o}}=\frac{\mathrm{I}_{1}}{\mathrm{~g}-(1-\delta)}
$$

and computed $\mathrm{K}_{\mathrm{o}}$ for each country with the first (1970) observed value of gross investment, the estimated value of $\mathrm{g}$ from A.6, and a predetermined value of $\delta$. Subsequently, we substituted the computed initial capital stock in A.1 to find the projected level of capital stock for the following year; and by subsequent substitutions, the timeseries of capital stock was produced. 


\section{PAPERS IN THE SERIES}

90-1 C-H. Hanf and D.J. Thampapillai, Optimal Taxation Policies for a Nonrenewable but Quasiinfinite Energy Resource: a Two-period Framework.

90-2 C. Nyland, Sexual Difference and Industrial Relations Research.

90-3 J. Halevi, Employment, Investment and Structural Maturity.

90-4 A. Levy, Repudiation, Retaliation, and the Secondary Market Price of Sovereign Debts.

90-5 A. Chaturvedi, V.H. Tran and G. Shukla, Performance of the Stein-rule Estimators when the Disturbances are Misspecified as Homoscedastic.

90-6 C. Nyland, John Locke and the Social Position of Women.

90-7 E.J. Wilson, Exchange Rate Variability. A Case of Non-Linear Rational Expectations.

90-8 E. Pol, Ray Scale Economies and Multiproduct Cost Functions.

90-9 V.H. Tran and A. Chaturvedi, Further Results on the Two-stage Hierarchical Information (2 SHI) Estimators in the Linear Regression Models.

90-10 A. Levy and T. Romm, Need Satisfaction Motivated Behaviour: Static and Dynamic Aspects.

90-11 A.H. Vanags, A Marshallian Model of Share Tenancy

90-12 A. Levy, An Analysis of the Potential Externalities Affecting the Borrowing Behaviour of Developing Countries.

90-13 Tran Van Hoa, System Estimation of Generalized Working Models: A Semiparametric Approach.

90-14 A. Chatuverdi, Tran Van Hoa and R. Lal, Improved Estimation of the Linear Regression Model with Autocorrelated Errors.

91-1 C. Nyland, Adam Smith, Stage Theory and the Status of Women.

91-2 A. Levy \& T. Romm, Optimal Timing of Migration: Expected Returns Risk Aversion and Assimilation Costs.

91-3 D.P. Chan \& K.Y. Cheung, Covered Interest Arbitrage Under the Linked Exchange Rate: Does it Exist? An Evidence from the Hong Kong Foreign Exchange Market.

91-4 M. M. Metwally, Role of Advertising in Oligopolistic Markets: Theory \& Evidence.

91-5 A. Levy \& T. Romm, The Consequences of Mutually Secured Debts: The Case of Israeli Moshavim.

91-6 Tran Van Hoa, Fundamentals of a new Macro-Modelling. Approach: With Application to Explaining and Forecasting Growth.

91-7 Boon-Chye Lee, A Sequential Bargaining Model of International Debt Renegotiation.

91-8 A. Levy, K. Chowdhury, \& E. Wilson, Are the External Debts of Developing Countries A Symptom or a Cause of Economic Slowdown?

91-9 Amnon Levy, A Pareto Optimal Condition for Bankruptcy and the Role of Variations in Aggregate Variables. 
91-10 K. Y. Cheung, On Testing the Joint Hypothesis of Short Term Interest Rate: A Single Extraction Approach.

91-11 Tran Van Hoa, How to Forecast Wage and Price Inflation with More Accuracy: The Australian Experience: $1945 / 50$ to 1988/89.

91-12 Amon Levy, Unemployment and Feedback Approach to the Management of Immigration by the Host Country.

92-1 Ann Hodgkinson, An Industry Policy Debate for the 1990s-What Lessons from the USA?

92-2 Lino Briguglio, Tourism Policies, Environmental Preservation and Sustainable Development on Small Islands: the Case of Malta.

92-3 Amnon Levy \& Khorshed Chowdhury, An Integrative Analysis of External Debt, Capital Accumulation and Production in Latin America, Asia-Pacific and Sub-Saharan Africa. 